\title{
Titania Nanostructures for Dye-sensitized Solar Cells
}

\author{
M. Malekshahi Byranvand ${ }^{1, *}$, A. Nemati Kharat ${ }^{1}, \quad$ M. H. Bazargan ${ }^{2}$
}

(Received 7 December 2012; accepted 28 November 2012; published online 30 December 2012)

\begin{abstract}
Titania is one kind of important materials, which has been extensively investigated because of its unique electronic and optical properties. Research efforts have largely focused on the optimization of the dye, but recently the titania nanostructures electrode itself has attracted more attention. It has been shown that particle size, shape, crystallinity, surface morphology, and chemistry of the $\mathrm{TiO}_{2}$ material are key parameters which should be controlled for optimized performance of the solar cell. Titania can be found in different shape of nanostructures including mesoporous, nanotube, nanowire, and nanorod structures. The present article reviews the structural, synthesis, electronic, and optical properties of $\mathrm{TiO}_{2}$ nanostructures for dye sensitized solar cells. Keywords: Titania nanostructures; Dye sensitized solar cells; Mesoporous; Nanotubes; Nanowires; Nanorods
\end{abstract}

Citation: M. Malekshahi Byranvand, A. Nemati Kharat and M. H. Bazargan, "Titania Nanostructures for Dye-sensitized Solar Cells", Nano-Micro Lett. 4 (4), 253-266 (2012). http://dx.doi.org/10.3786/nml.v4i4. p253-266

\section{Introduction}

The world demand for clean and cheap energy from sustainable sources is requiring important research efforts in diverse areas, including electricity production, storage and distribution. Since the discovery of the photovoltaic effect in 1839 by Alexandre-Edmond Becquerel, research has been increased in this field, particularly during the last 20 years when the need for renewable energy sources has become more critical [1]. The commercialized crystalline silicon-based solar cells are now reaching energy conversion efficiency around $25 \%$ [2]. Other materials and technologies are being developed to achieve lower costs and more flexibility. Among the promising low-cost solar cells, dye-sensitized solar cells (DSC) are under active scrutiny [1].

A breakthrough in the efficiency was reported in 1991 [3]. Based on a film of nanostructured titanium dioxide $\left(\mathrm{TiO}_{2}\right)$ sensitized with a ruthenium complex and on an organic electrolyte, an energy conversion efficiency about $7.5 \%$ was achieved under simulated solar light illumination. A schematic representation of operating principles of a typical DSC is illustrated in Fig. 1 [1]. The dye is placed over $\mathrm{TiO}_{2}$ film in contact with an electrolyte. Via absorption of a photon (excitation) by dye covered on nanocrystalline $\mathrm{TiO}_{2}$, electron changes from the electronic ground state $\left(\mathrm{S}^{0}\right)$ to the excited state $\left(\mathrm{S}^{*}\right)$. The excitation of the dye $\left(\mathrm{S}^{*}\right)$ upon irradiation is followed by injection of the resulting electrons into the conduction band $(\mathrm{CB})$ of the semiconductor, from where they reach the cell anode. Regeneration of dye $\left(\mathrm{S}^{+}\right)$electrons occurs through electron donation from a redox electrolyte in contact with the dye $\left(\mathrm{S}^{0}\right)$. This typically occurs through an organic solvent containing an iodide/triiodide $\left(\mathrm{I}^{-} / \mathrm{I}_{3}^{-}\right)$couple. Triiodide is reduced in turn at the counter electrode, while electron migration from the anode to the cathode (counter electrode) closes the circuit [4]. The voltage generated is equal to the difference between the Fermi level of the electron in the solid $\mathrm{TiO}_{2}$ and the redox potential of the electrolyte $[5,6]$.

\footnotetext{
${ }^{1}$ School of Chemistry, University College of Science, University of Tehran, Tehran, Iran

${ }^{2}$ Iranian Research Organization for Science and Technology (IROST), Tehran, Iran

*Corresponding author. E-mail: mahdi.malekshahi@gmail.com
} 


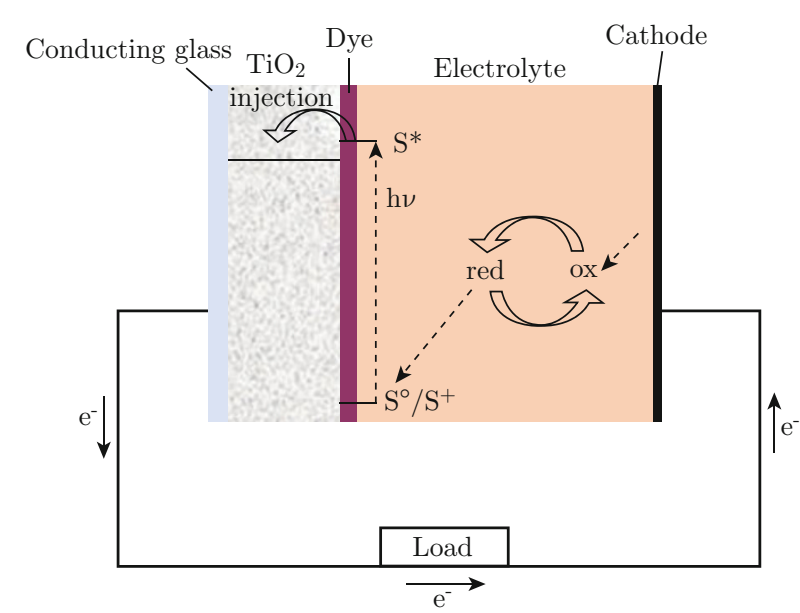

Fig. 1 Schematic diagram of the DSC.

Since that breakthrough, research has been growing exponentially in order to increase the efficiency or the stability of dye sensitized solar cells through the optimization of their components. Among others, a factor was responsible for this significant progress: the use of nanostructured $\mathrm{TiO}_{2}$, providing a large surface area and thus allowing a larger amount of dye to be attached to the $\mathrm{TiO}_{2}$ surface $[7,8]$. A high performance
DSC requires the $\mathrm{TiO}_{2}$ film with proper small particle size and mesoporosity so that a large amount of dye can be adsorbed for achieving high photoelectric conversion efficiency in DSC [9].

$\mathrm{TiO}_{2}$ exists in three mineral forms: anatase, rutile and brookite [10]. Anatase type $\mathrm{TiO}_{2}$ has a crystalline structure that corresponds to the tetragonal system (with dipyramidal habit) and is used mainly as a photocatalyst under UV irradiation. Rutile type $\mathrm{TiO}_{2}$ also has a tetragonal crystal structure (with prismatic habit). This type of titania is mainly used as white pigment in paint. Brookite type $\mathrm{TiO}_{2}$ has an orthorhombic crystalline structure. In general, $\mathrm{TiO}_{2}$ is preferred in anatase and rutile form because of its high specific area, non-toxic, photochemically stable and relatively in-expensive [11-13].

Titania nanostructured thin films are of interest for various applications including microelectronics, optical cells, solar energy conversion, highly efficient catalysts, microorganism photolysis, antifogging and self-cleaning coatings, gratings, etc [14]. Solar cells based on titania nanostructured films have been widely studied $[7,15$ 19]. At the heart of the DSC is a nanocrystalline mesoporous $\mathrm{TiO}_{2}$ film with a monolayer of the charge transfer dye attached to its surface (Fig. 2(a)) [20].

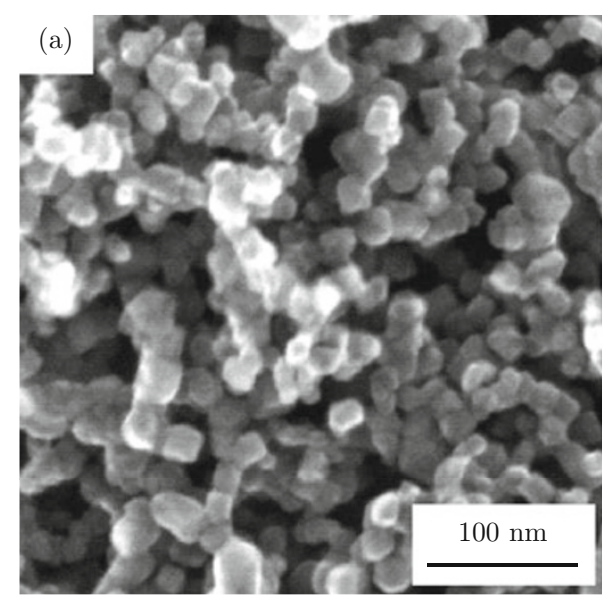

(b)

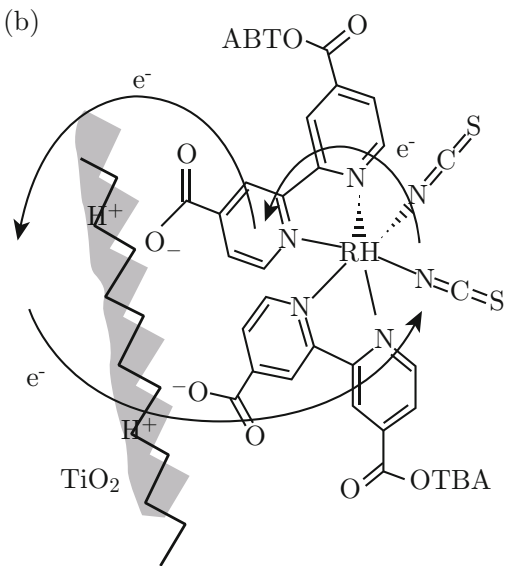

(c)

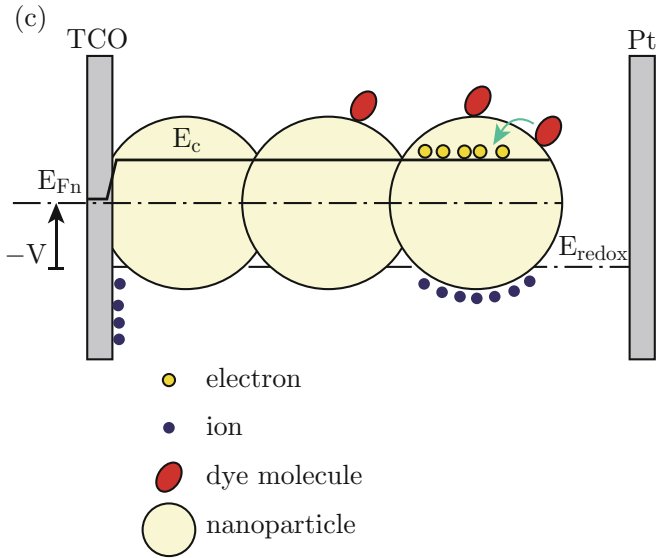

Fig. 2 (a) SEM picture of a Titania nanostructured film used in DSC; (b) adsorption of a dye molecule on TiO 2 film; and (c) electron transfer in DSC. 
Photoexcitation of the dye injects an electron into the conduction band of $\mathrm{TiO}_{2}$ (Fig. 2(b)) [20]. The electron can be conducted to the outer circuit to drive the load and make electric power. The original state of the dye is subsequently restored by electron donation from the electrolyte, usually an organic solvent containing a redox system, such as the iodide/triiodide couple. The regeneration of the sensitizer by iodide prevents the recapture of the conduction band electron by the oxidized dye. The iodide is regenerated in turn by the reduction of triiodide at the counter electrode, with the circuit being completed via electron migration through the external load. The voltage generated under illumination corresponds to the difference between the Fermi level of $\mathrm{TiO}_{2}$ and the redox potential of the electrolyte (Fig. 2(c)) [20]. Overall, the device generates electric power from light without suffering any permanent chemical transformation [7,15-19].

The oxide material of choice for many of these systems has been $\mathrm{TiO}_{2}$ [21-23]. Its properties are intimately depended to the material content, chemical composition, structure and surface morphology. Fortunately colloid chemistry has greatly developed in the last two decades. It is now possible to control the processing parameters such as precursor chemistry, hydrothermal growth temperature, binder addition and sintering conditions and optimize the key parameters of the film, namely, porosity, pore size distribution, light scattering, electron percolation. On the material content and morphology, two crystalline forms of anatase and rutile for $\mathrm{TiO}_{2}$ are important (the third form brookite is difficult to obtain). Anatase is the low temperature stable form and gives mesoscopic films that are transparent and colorless. The predominant morphology of the particles is bipyramidal exposing well-developed (101) faces [24].

Titania has been observed mainly in different forms of nanostructures such as mesoporous [25], nanotube [26], nanowire [27] and nanorod [28] structures. The structural, synthesis, electronic and optical properties of $\mathrm{TiO}_{2}$ nanomaterials for DSC are reviewed in the next section.

In this review, we focus on some of the developments of titania nanostructures for applications in DSC. In addition we summarize the synthesis pathways and morphology of the nanostructured titanium dioxide.

\section{Mesoporous $\mathrm{TiO}_{2}$ films}

Preparation of mesoporous $\mathrm{TiO}_{2}$ films consists of two steps: first, a colloidal solution containing nanosized particles of the oxide is formed which is used subsequently to produce a few micron thick films with good electrical conduction properties [20,24]. In a typical synthesis process, a nanocrystalline $\mathrm{TiO}_{2}$ film involves controlled hydrolysis of a Ti (IV) salt, usually an alkoxide such as Ti-isopropoxide or a chloride followed by peptization [5]. In order to obtain particles of desired size, the hydrolysis and condensation kinetics must be controlled. Ti-alkoxides with bulky groups such as butoxide hydrolyze slowly allowing slow condensation rates. Autoclaving of these sols (heating at $200 \sim 250^{\circ} \mathrm{C}$ for $12 \mathrm{~h}$ ) allows controlled growth of the primary particles and also to some extent, the crystallinity [24].

During this hydrothermal growth smaller particles dissolve and fuse to large particles by a process known as 'Ostwald ripening'. After removal of solvent and addition of a binder the sol is now ready for deposition on the substrate. For the latter, a conducting glass sheet is often used and the sol is deposited by doctor blading or screen printing and fired in air for sintering. The film thickness is typically $1 \sim 20 \mu \mathrm{m}$ and the film mass approximately $1 \sim 2 \mathrm{mg} / \mathrm{cm}^{2}$. Analysis of the porous films shows the porosity to be approximately $50 \%$ (the average pore size being $15 \mathrm{~nm})$.

Figure 3(a), 3(b), 3(c), 3(d), 3(e) [20] illustrate the morphology of several nanocrystalline $\mathrm{TiO}_{2}$ (anatase) layers deposited on a transparent conducting oxide (TCO) glass at different temperatures. The morphology of the particles is controlled by the temperature of the hydrothermal treatment used for film preparation [20]. Interestingly, self-organization of the nanoparticles is observed at below $240^{\circ} \mathrm{C}$.

Zukalova et al. found that ordered mesoporous $\mathrm{TiO}_{2}$ nanocrystalline films showed enhanced solar conversion efficiency by about $50 \%$ compared to traditional films of the same thickness made from randomly oriented anatase nanocrystals [29]. The $\mathrm{TiO}_{2}$ nanocrystalline film was prepared via layer- by-layer deposition with Pluronic P123 as template. The sensitizer used was cis-dithiocyanato(4,4/-dicarboxy-2,2/bipyridine)(4,4/-di-(2-(3,6-dimethoxyphenyl)ethenyl)2,2/-bi-pyridine) ruthenium (II), N945. Figure 4 [23,29] shows the photocurrent-voltage characteristics for solar cells based on $\mathrm{TiO}_{2}$ films. When sensitized by N945, the $0.95 \mu \mathrm{m}$ thick nonorganized anatase film gave a conversion efficiency of only $2.21 \%$, which increased to $2.74 \%$ with surface treatment by $\mathrm{TiCl}_{4}$ prior to dye deposition. Under standard global AM 1.5 solar conditions, the cell with an ordered mesoporous $\mathrm{TiO}_{2}$ nanocrystalline film gave a photocurrent density of $\mathrm{I}_{\mathrm{P}}=7 \mathrm{~mA} / \mathrm{cm}^{2}$, an open circuit potential of $\mathrm{V}_{\mathrm{OC}}=$ $0.799 \mathrm{~V}$, and a fill factor of $\mathrm{FF}=0.72$, yielding $4.04 \%$ conversion efficiency. This improvement resulted from a remarkable enhancement of the short circuit photocurrent, due to the huge surface area accessible to both the dye and the electrolyte [29]. 

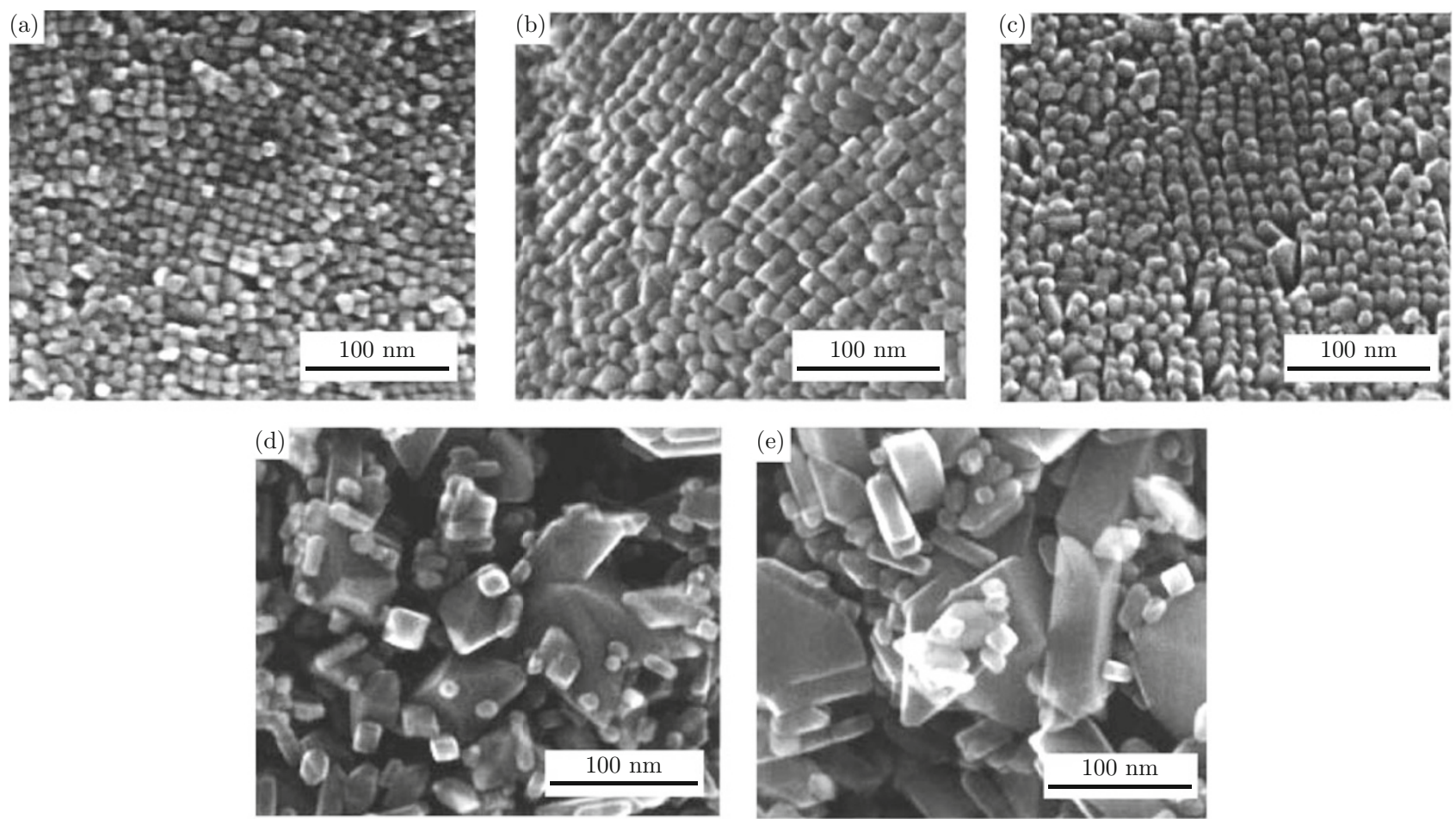

Fig. 3 SEM micrographs of thin films deposited using a colloid autoclaved at (a) 190; (b) 210; (c) 230; (d) 250; and (e) $270^{\circ} \mathrm{C}$.

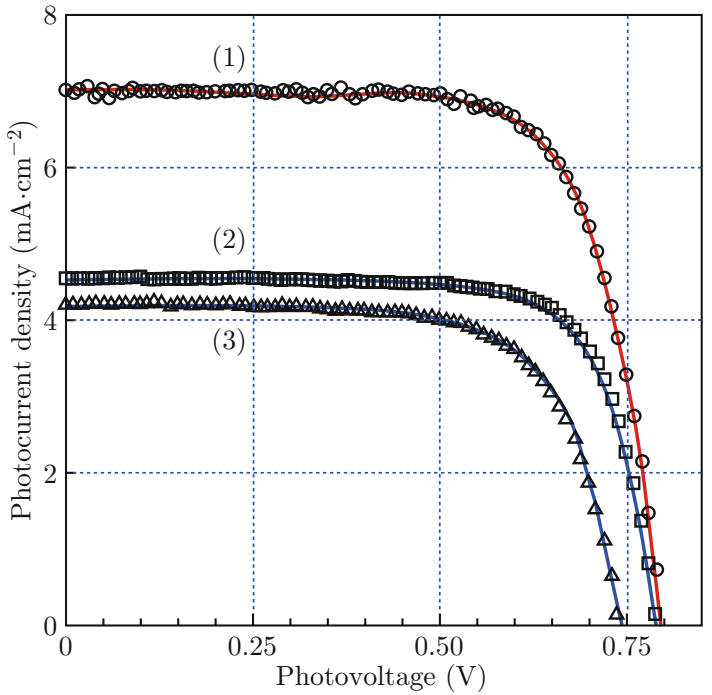

Fig. 4 Photocurrent-voltage characteristics of a solar cell, based on $\mathrm{TiO}_{2}$ films sensitized by N945. (1) Pluronic templated three-layer film; (2) $1.0 \mu \mathrm{m}$-thick, nonorganized anatase treated by TiCl4, $0.95 \mu \mathrm{m}$-thick; (3) nonorganized anatase nontreated by $\mathrm{TiCl}_{4}, 0.95 \mu \mathrm{m}$-thick.

\section{$\mathrm{TiO}_{2}$ Nanotubes films}

Generally, the rate-limiting factor is the dynamic competition between the electron transport in the $\mathrm{TiO}_{2}$ and interfacial recombination of electrons. Typically the electron transport time constants in $\mathrm{TiO}_{2}$ nanoparticles are comparably slow (due to a trapping/de- trapping type of electron transport) [30-34].

Low electron diffusion coefficients within the $\mathrm{TiO}_{2}$ nanoparticles can be due to defects, surface states, grain boundaries and etc. that act as electron trapping sites, thus slowing down electron flow, enhancing recombination and thereby diminishing the electron collection at the back contact [35-37]. In order to considerably improve this behavior, recently research has been prompted towards the use of onedimensional (1D) nanostructures of $\mathrm{TiO}_{2}$, such as, nanotubes [38,39], nanorods $[40,41]$, nanowires $[25,42]$ and etc. These 1D nanostructures are expected to significantly improve the electron transport properties due to a directional smooth electron mobility (limiting random walk in the wide nanocrystalline network) as well as decreased inter-crystalline contacts, thereby accelerating electron transport and lowering the recombination probability as shown in the schematic diagram of Fig. 5(a), 5(b) [43,44].

Various techniques for synthesizing $\mathrm{TiO}_{2}$ nanotubes and other 1D structure have been reported in recent years, such as sol-gel processes or hydrothermal approaches [45-47].

Although comparably high efficiency solar cells have been produced with these chemically synthesized 1D morphologies of $\mathrm{TiO}_{2}$, a multidirectional orientation of $\mathrm{TiO}_{2}$ nanotubes or nanorods may not ensure the most efficient unidirectional electron flow along the length of a restricted passage towards the back contact. In principle, as long as the nanotube or nanorod systems are 


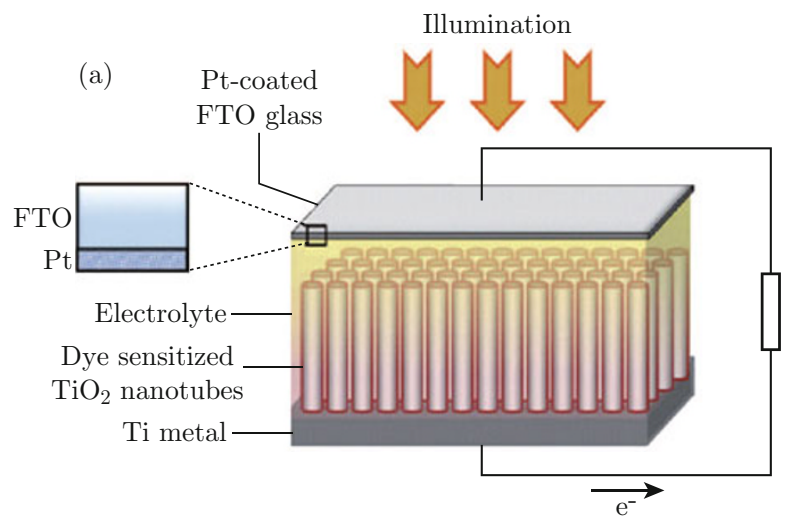

(b)

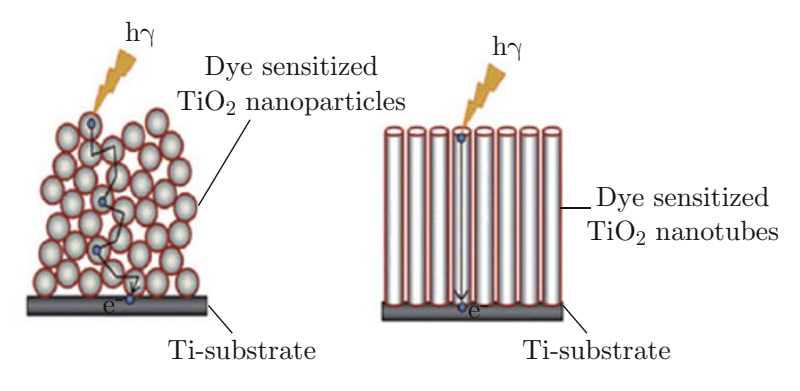

Fig. 5 (a) Schematic representation of typical solar cell construction using $\mathrm{TiO}_{2}$ nanotubes grown on a Ti substrate; (b) A comparison of the electron pathways through nanoparticulate and nanotubular structured $\mathrm{TiO}_{2}(3 \mathrm{D}$ random walk vs. $1 \mathrm{D}$ transport).

ideal i.e., they provide a highly conductive, rapid electron transport, their orientation on the substrate is of minor importance. This, for example, may hold for single crystalline defect-free nanowires [30]. However, many approaches to grow $\mathrm{TiO}_{2}$ nanotubes lead to a polycrystalline material with substantial recombination possibilities along the electron path. In this case the optimally increased rate of electron transport and the higher charge collection efficiencies can only be expected for nanotubes vertically aligned with the conductive substrate. Therefore approaches to produce self-ordered titania nanotubes by anodic oxidation of $\mathrm{Ti}$ in adequate electrolyte have become of a significant interest and the present review will focus on this point in later sections but will first give a brief overview of some general concepts in DSCs [48].

Self-organized $\mathrm{TiO}_{2}$ nanotube layers as shown in Fig. 6 [31] are formed by anodic oxidation of a Ti-metal sheet (illustrated in Fig. 6(a)). This simple electrochemical process can be carried out in an electrochem- ical cell with a two- or three-electrode system: Ti-foil as the working electrode (the anode) and for example $\mathrm{Pt}$ as the counter electrode, and using a standard voltage source or a high-voltage potentiostat. The key to forming self-ordered nanotube layers on the metal substrate is that samples are anodized under a set of optimized conditions in solutions containing fluoride ions. Reviews of this topic have recently been published [48].

The process originates from work by Zwilling and coworkers published in 1999, on the anodization of $\mathrm{Ti}$ and $\mathrm{Ti}$ alloys in chromic acid-HF mixtures [49]. These authors could grow the first generation of tubes to layers of a thickness of few $100 \mathrm{~nm}$. Later on, this process was used by Beranek et al. [50] to grow organized $\mathrm{TiO}_{2}$ nanotubular layers in aqueous $\mathrm{HF}$ electrolytes or $\mathrm{H}_{2} \mathrm{SO}_{4} / \mathrm{HF}$ electrolytes to establish better defined growth conditions. However, although considerable order in wall thickness, diameter and short-range arrangement was established, the tube length remained limited to $\sim 500 \mathrm{~nm}$ and the walls showed considerable disorder

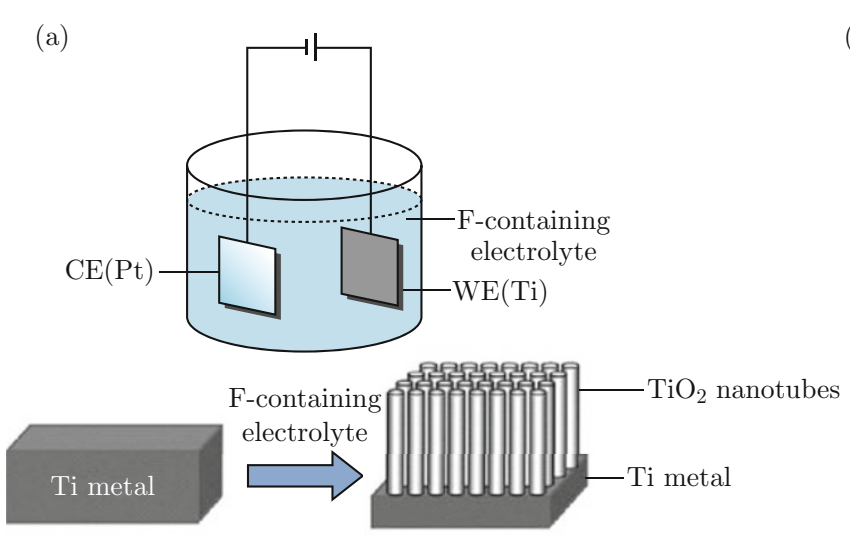

(b)
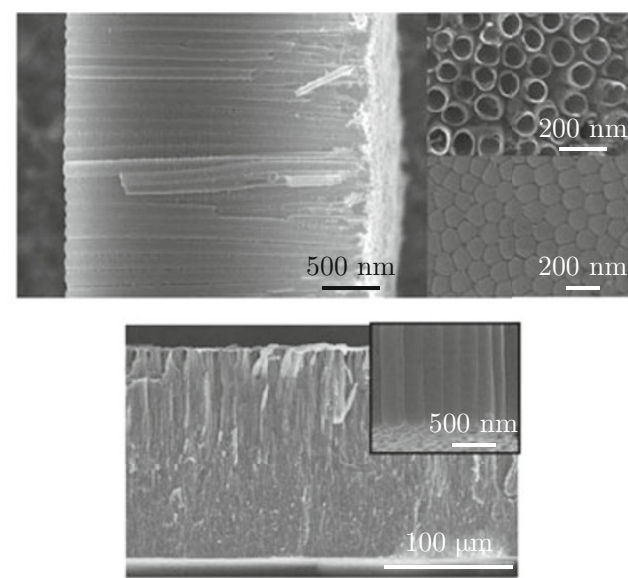

Fig. 6 (a) Schematic diagram of an electrochemical set-up and anodic growth of $\mathrm{TiO}_{2}$ nanotubes on a Ti-metal sheet; (b) SEM images of $\mathrm{TiO}_{2}$ nanotube layers formed by the anodic oxidation of Ti-metal in non-aqueous electrolyte (cross section, top view and bottom view) and also showing a very high-aspect-ratio nanotube layer (several hundred mm). 
(side-wall ripples and other etch effects). Two key steps in improving the geometry were introduced by Macak et al [51-53] (i) the use of neutral electrolytes that allowed, under suitable conditions, significantly longer tubes to be grown, and (ii) the use of non-aqueous electrolytes that allowed to significantly improve the tube wall roughness (smooth, high aspect ratio nanotubes).

Using such an anodization procedure in non-aqueous electrolytes, not only very thick $\mathrm{TiO}_{2}$ nanotube layers (several $100 \mathrm{~mm}$ ) can be grown but they also show a very smooth wall 83 and can be grown to show an almost ideal hexagonal arrangement (Fig. 6(b)) [31].

Adachi et al. found that dye-sensitized solar cells with electrodes made of disordered single-crystalline $\mathrm{TiO}_{2}$ nanotubes (10 $\mathrm{nm}$ diameter, 30 300 $\mathrm{nm}$ length) displayed an efficiency of $4.88 \%$, showing more than double the short-circuit current density compared to those made of $\mathrm{TiO}_{2}$ nanoparticles of Deguessa P-25 in a similar thin-film thickness region [54]. Macak et al. found that, for Ru-dye (N3) sensitization of selforganized $\mathrm{TiO}_{2}$ nanotubes grown by Ti anodization, IPCE max values (at $540 \mathrm{~nm}$ ) of $3.3 \%$ and $1.6 \%$ (at $530 \mathrm{~nm}$ ) were obtained for $2.5 \mu \mathrm{m}$ and $500 \mathrm{~nm}$ long nanotubes, respectively [55]. Ohsaki et al. found that the higher efficiency of solar cells with $\mathrm{TiO}_{2}$ nanotubebased electrodes resulted from an increase in electron density in nanotube electrodes compared to P25 electrodes [56].

Grimes et al. fabricated highly ordered nanotube arrays (46 $\mathrm{nm}$ pore diameter, $17 \mathrm{~nm}$ wall thickness, and $360 \mathrm{~nm}$ length) grown perpendicular to an Fdoped $\mathrm{SnO}_{2}$-coated glass substrate by anodic oxidization [57]. After crystallization by oxygen annealing and treatment with $\mathrm{TiCl}_{4}$, the nanotube arrays were integrated into a DSC structure using a commercially available ruthenium-based dye N719. The cell generated a photocurrent of $7.87 \mathrm{~mA} / \mathrm{cm}^{2}$ with a photocurrent efficiency of $2.90 \%$, using a 360-nm-thick electrode under AM 1.5 illumination. They found that the highly ordered $\mathrm{TiO}_{2}$ nanotube arrays had superior electron lifetimes and provided excellent pathways for electron percolation in comparison to nanoparticulate systems. Figure 7 [57] shows the photocurrentphotovoltage characteristics of the $\mathrm{TiO}_{2}$ nanotube DSC. They also found that backside illuminated solar cells based on $6 \mu \mathrm{m}$ long highly ordered nanotubes array films sensitized by bis(tetrabutylammonium)-cis(dithiocyanato)- $N, N$-bis(4-carboxylato-4-carboxylic acid-2,2-bipyridine) ruthenium(II) (N719) showed a power conversion efficiency of $4.24 \%$ under AM 1.5 illumination [58].

Nowadays, even more advanced geometries of $\mathrm{TiO}_{2}$ nanotubes can be prepared by different methods [44, 59-63]. For example, Zheng et al. reported the influence of hierarchical structures, constructed via layer- by-layer assembly of self-standing titania nanotube arrays and nanoparticles, upon charge recombination and photoelectric performance of front-illuminated DSCs [64]. Both nanotubes and nanoparticles were produced by anodization rather than additionally employing other methods, providing low cost and great simplicity (Fig. 8) [64]. Electrochemical impedance spectroscopy under AM 1.5 illumination indicates the construction of hybrid morphology has superior recombination characteristics and a longer electron lifetime than nanoparticulate systems. This enhancement with the incorporation of anodized titania nanoparticles with $1 \mathrm{D}$ architectures is unprecedented for solar cells. They achieve better light harvesting efficiency, extended electron lifetime and desirable electron extraction, the short-circuit photocurrent density of solar cell is 18.89 $\mathrm{mA} / \mathrm{cm}^{2}$ with an overall power conversion efficiency of $8.80 \%$ and an incident photon-to-current conversion efficiency of $84.60 \%$ providing a very promising candidate for sustainable energy production with a high performance/cost ratio [64].

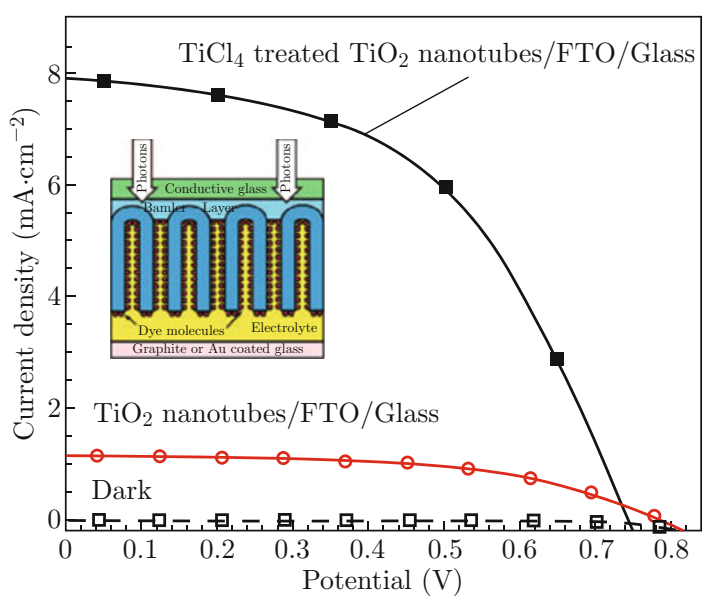

Fig. 7 Photocurrent photovoltage characteristics of a transparent nanotube array DSC under 100\% AM-1.5 illumination.

\section{$\mathrm{TiO}_{2}$ nanowires films}

$\mathrm{TiO}_{2}$ nanowires are another important 1D nanostructure that has also attracted a lot of interests regarding an application in DSCs [65-69]. Hydrothermal growth has been reported to be a novel method for synthesis of $\mathrm{TiO}_{2}$ nanowire array on FTO glass substrate. In this method, tetrabutyltitanate and/or titanium tetrachloride were used as the precursor, to which an $\mathrm{HCl}$ solution was added to stabilize and control the $\mathrm{pH}$ of the reaction solution. Growth typically occurring at 180$220^{\circ} \mathrm{C}$ for $\sim 24 \mathrm{~h}$ might form nanowires $35 \sim 90 \mathrm{~nm}$ in the lateral dimension and $\sim 4 \mu \mathrm{m}$ in the length (Fig. 9(a)) [67]. 

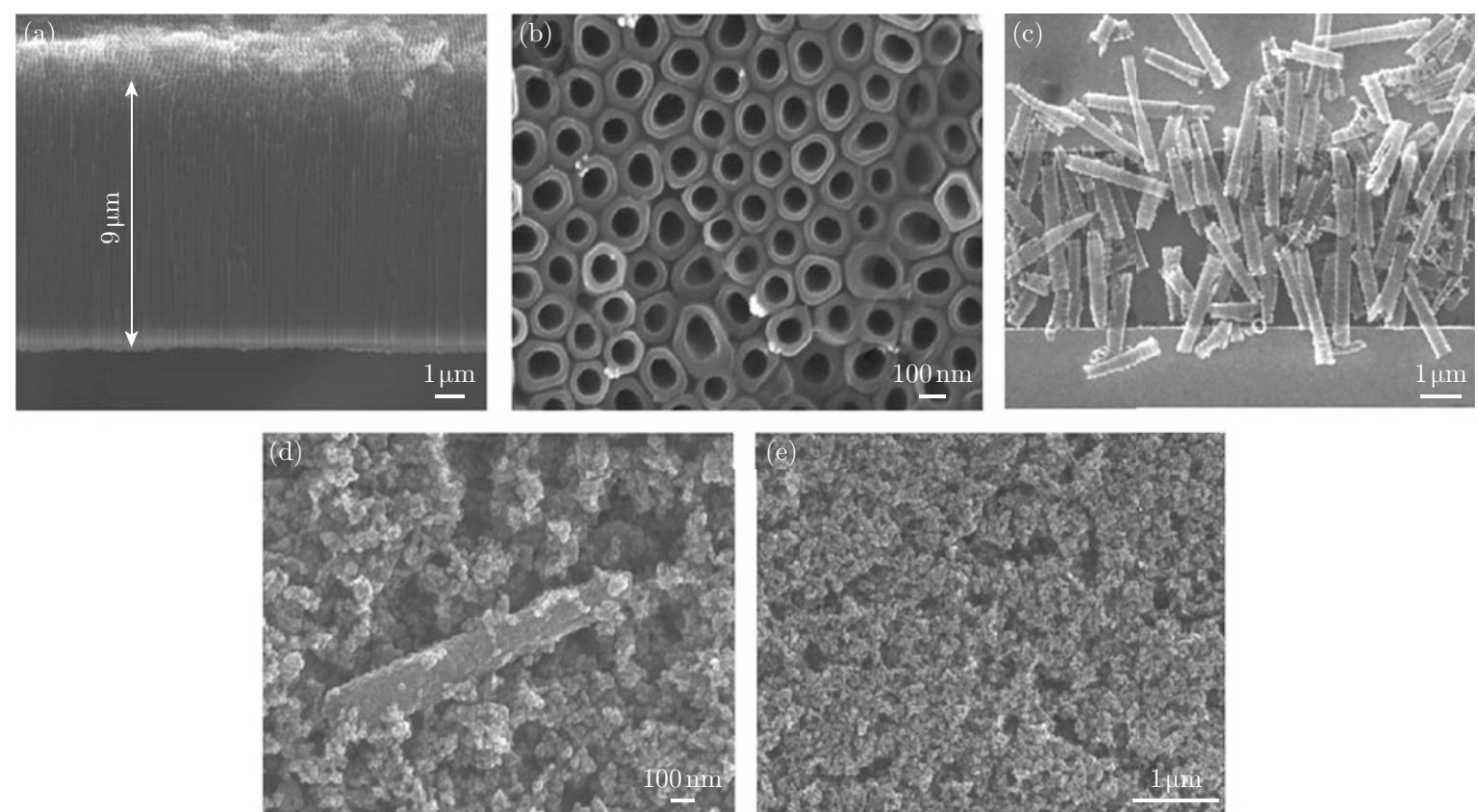

Fig. 8 (a) SEM images of crosssectional view of self-standing $\mathrm{TiO}_{2}$ nanotube arrays and $\mathrm{TiO}_{2}$ nanoparticles; (b) top view of $\mathrm{TiO}_{2}$ nanotube arrays; (c) randomly oriented $\mathrm{TiO}_{2}$ nanotubes after sonication; (d, e) mesoporous $\mathrm{TiO}_{2}$ nanoparticulate film at different magnifications.
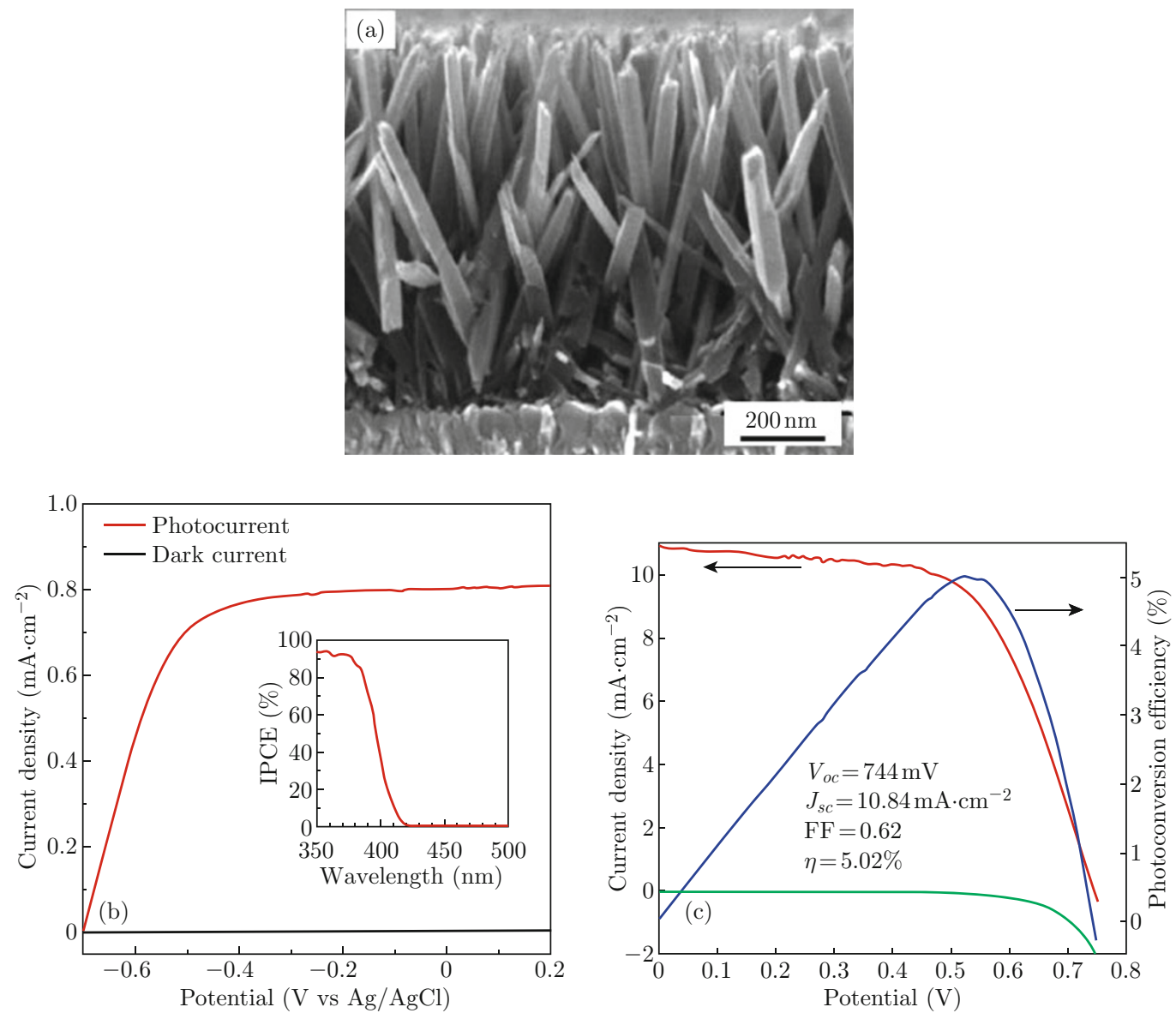

Fig. 9 DSCs with $\mathrm{TiO}_{2}$ nanowires: (a) cross-sectional SEM image of $\mathrm{TiO}_{2}$ nanowire array grown on transparent conductive substrate; (b) photocurrent density of a $\mathrm{TiO}_{2}$ nanowires photoelectrode film as a function of measured potential in $1 \mathrm{M} \mathrm{KOH}$ under AM 1.5 illumination (the inset shows the IPCE spectrum); and (c) photovoltaic response of a $\mathrm{TiO}_{2}$ nanowire solar cell. 
The dependence of photocurrent density on the measured potential was studied while the $\mathrm{TiO}_{2}$ nanowires were under AM 1.5 illumination, revealing a saturated photocurrent at the bias of approximately $-0.25 \mathrm{~V}$ (vs reference electrode) (Fig. 9(b)) [66]. Compared with a positive bias in the range of $0.5 \sim 1 \mathrm{~V}$ needed in the nanoparticle electrode to completely separate the photogenerated electron-hole pairs, such a low bias indicated that the nanowires possessed a low series resistance and had more effective capability of facilely separating the photogenerated charges. This is in agreement with what is presented in the incident photo to collected electron (IPCE) spectrum of $\mathrm{TiO}_{2}$ nanowires (inset of Fig. 9(b)), in which the efficiency is shown to reach a maximum of approximately $90 \%$, implying a low charge recombination in the nanowire/electrolyte system. Test of the solar cell performance of the $\mathrm{TiO}_{2}$ nanowires with a standard DSC configure revealed an overall conversion efficiency of $5 \%$ (Fig. 9(c)) [66], which is obviously much higher than those of $1.2 \sim 1.5 \%$ reported for $\mathrm{ZnO}$ nanowires even with length up to $40 \mu \mathrm{m}[70,71]$. This more likely resulted from a better coupling of the nanowires of $\mathrm{TiO}_{2}$ with the ruthenium-based dye molecules, whereas it is well-known that the $\mathrm{ZnO}$ lacks stability in an acid dye solution and therefore may form a $\mathrm{Zn}^{2+}$ /dye complex on the surface which seriously retards the electron injection $[67,71,72]$.

In the 2011, Wei et al. reported the highly ordered, vertically oriented $\mathrm{TiO}_{2}$ nanowire arrays that synthesized directly on transparent conducting substrate by solvothermal procedure without any template [73]. The X-ray diffraction (XRD) pattern shows that $\mathrm{TiO}_{2}$ array is in rutile phase growing along the $\left(\begin{array}{lll}0 & 0 & 2\end{array}\right)$ direction (Fig. 10). The field-emission scanning electron microscopy (FE-SEM) images of the samples indicate that the $\mathrm{TiO}_{2}$ array surface morphology and orientation are highly dependent on the synthesis conditions (Fig. 11). In a typical condition of solvothermal at $180^{\circ} \mathrm{C}$ for $2 \mathrm{~h}$, the $\mathrm{TiO}_{2}$ nanowire arrays are composed of nanowires $10 \pm 2 \mathrm{~nm}$ in width, and several nanowires bunch together to form a larger secondary structure of $60 \pm 10$ $\mathrm{nm}$ wide. Dye-sensitized solar cell assembled with the $\mathrm{TiO}_{2}$ nanowire arrays grown on the FTO glass as photoanode under illumination of simulated AM 1.5G solar light $\left(100 \mathrm{~mW} / \mathrm{cm}^{2}\right)$ achieves an overall photoelectric conversion efficiency of $1.64 \%$ [73].

\section{$\mathrm{TiO}_{2}$ nanorods films}

Besides $\mathrm{TiO}_{2}$ nanoparticles, $\mathrm{TiO}_{2}$ nanorods have also been synthesized with the hydrothermal method. Hafez et al. obtained $\mathrm{TiO}_{2}$ nanorods by treating a dilute $\mathrm{TiCl}_{4}$ solution at $333 \sim 423 \mathrm{~K}$ for $12 \mathrm{~h}$ in the presence of acid or inorganic salts. Figure 12 shows a typical transmission electron micrograph (TEM) image of the $\mathrm{TiO}_{2}$ nanorods prepared with the hydrothermal method [7476]. Figure 12 shows the photocurrent density-voltage $(\mathrm{J}-\mathrm{V})$ characteristics of a DSC based on the hybrid nanorods/nanoparticles $(\mathrm{NR} / \mathrm{NP})$ bilayer titania electrode (approximately $12 \mu \mathrm{m}$ in total thickness) [27].

The performance of the DSCs based on this bilayer film was measured under 1 Sun AM 1.5 simulated sunlight. The $\mathrm{J}_{\mathrm{SC}}, \mathrm{V}_{\mathrm{OC}}, \mathrm{FF}$, and $\eta$ of the bilayer electrode were found to be $14.45 \mathrm{~mA} / \mathrm{cm}^{2}, 0.76 \mathrm{~V}$, 0.65 , and $7.10 \%$, respectively. The comparison between photocurrent-voltage characteristics of the DSC using the $\mathrm{TiO}_{2} \mathrm{NR} / \mathrm{NP}$ bilayer electrode with those of cells using pure $\mathrm{TiO}_{2} \mathrm{NR}$ and NP electrodes (with the same film thickness) are shown in Fig. 13. The photoelectrical data of the DSCs are summarized in Table 1. From the results in Fig. 4 and the data in Table 1, it can be seen that high short photocurrent density, as well as high photovoltaic performance, have been obtained by applying the hybrid design $\mathrm{TiO}_{2} \mathrm{NR} / \mathrm{NP}$ bilayer electrode in the DSC than that of pure NR and NP devices $[27]$.
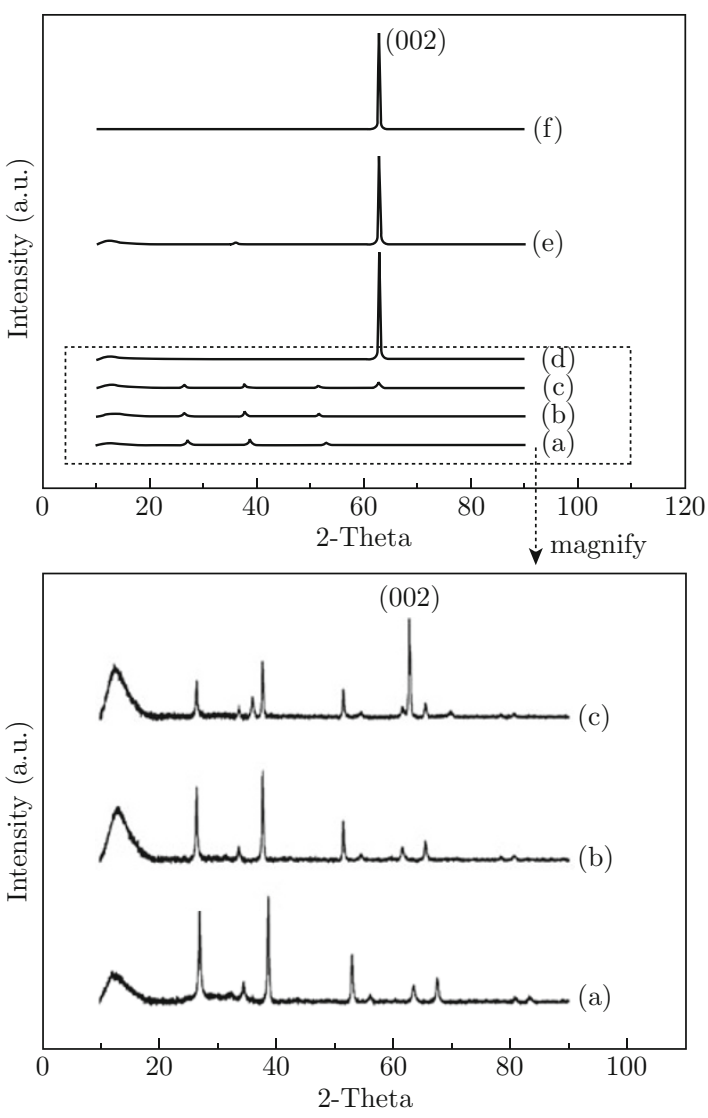

Fig. 10 XRD patterns of $\mathrm{TiO}_{2}$ nanowire arrays fabricated at $180^{\circ} \mathrm{C}$ for different duration: (a) FTO glass; (b) $0.5 \mathrm{~h}$; (c) $1 \mathrm{~h}$; (d) $2 \mathrm{~h}$; (e) $4 \mathrm{~h}$; and (f) $6 \mathrm{~h}$. 


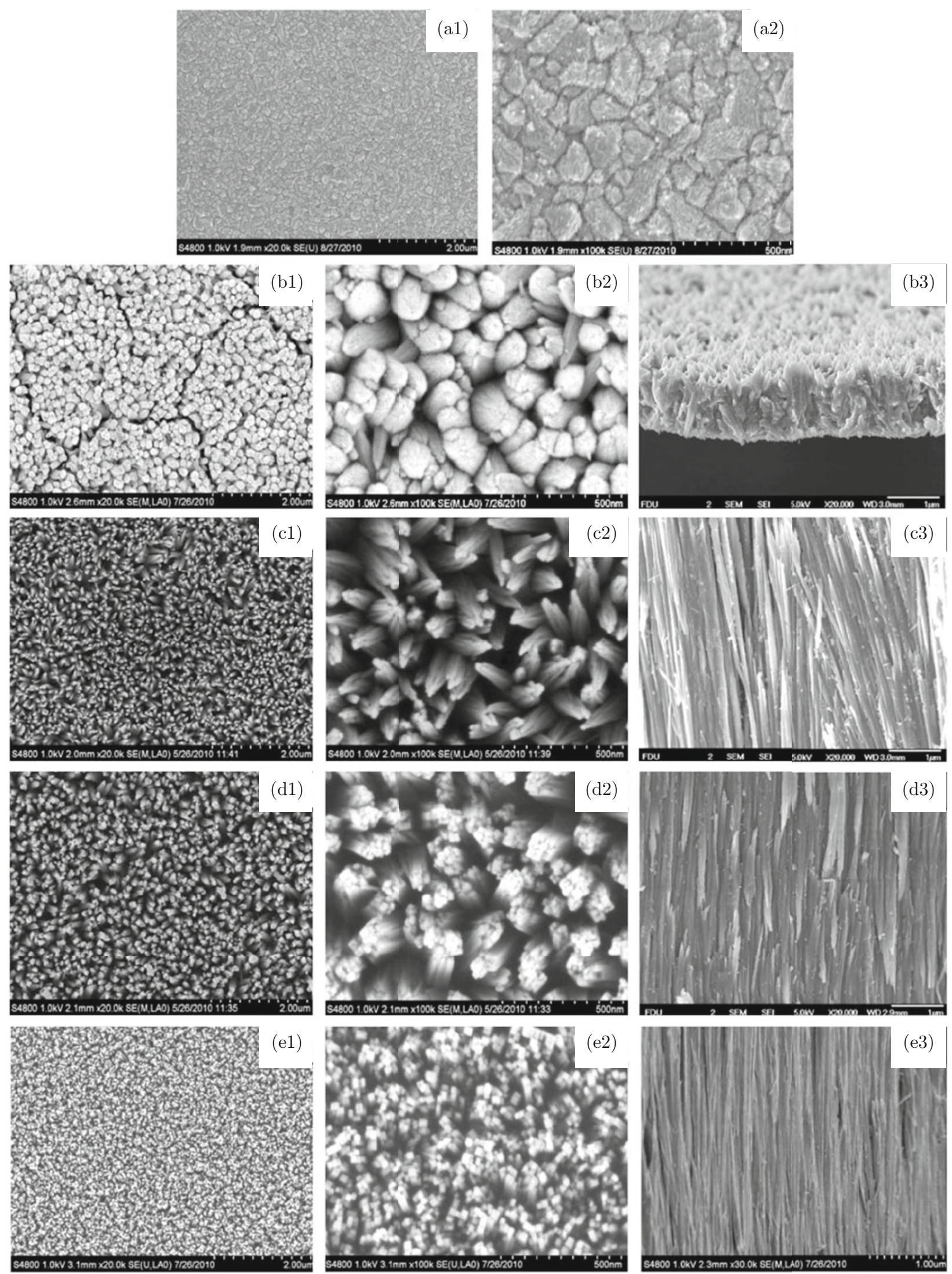

Fig. 11 FE-SEM images of $\mathrm{TiO}_{2}$ nanowire arrays fabricated at $180^{\circ} \mathrm{C}$ for different duration: (a1 and a2) $0.5 \mathrm{~h}$; (b1-b3) 1 h; (c1-c3) 2 h; (d1-d3) 4 h; and (e1-e3) 6 h. 

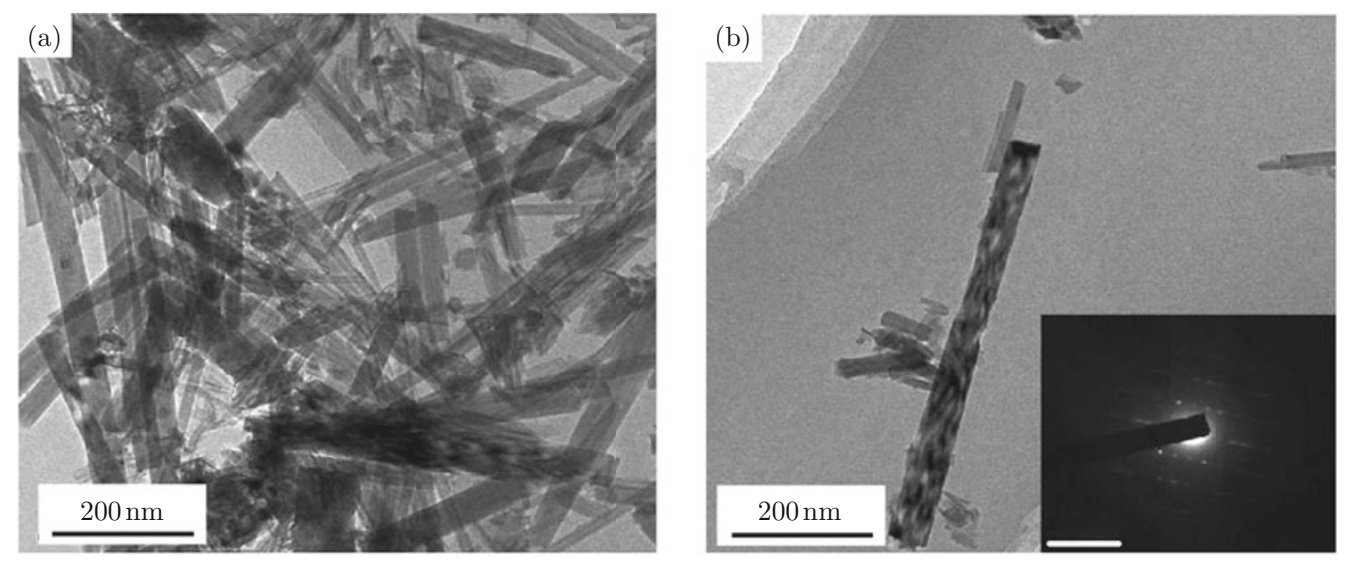

Fig. 12 (a) TEM images of the $\mathrm{TiO}_{2}$ nanorods sample. The inset in (b) is the corresponding SAED patterns of the nanorods.

Table 1 The parameters of the dye-sensitized solar cells with the different $\mathrm{TiO}_{2}$ electrodes.

\begin{tabular}{|c|c|c|c|c|c|c|}
\hline Electrode & $\begin{array}{c}\text { Adsorbed dye } \\
\left(10^{-5} \mathrm{~mol} \cdot \mathrm{cm}^{-2}\right)\end{array}$ & IPCE (at $575 \mathrm{~nm}$ ), \% & $J_{\mathrm{sc}}\left(\mathrm{mA} \cdot \mathrm{cm}^{-2}\right)$ & $V_{\propto}(\mathrm{V})$ & $\mathrm{FF}$ & $\eta, \%$ \\
\hline Pure NR & 2.1 & 63.5 & 8.88 & 0.739 & 0.67 & 4.4 \\
\hline Pure NP & 3.6 & 70.0 & 11.89 & 0.738 & 0.67 & 5.8 \\
\hline $\mathrm{NR} / \mathrm{NP}$ & 6.2 & 88.9 & 14.45 & 0.756 & 0.65 & 7.1 \\
\hline
\end{tabular}

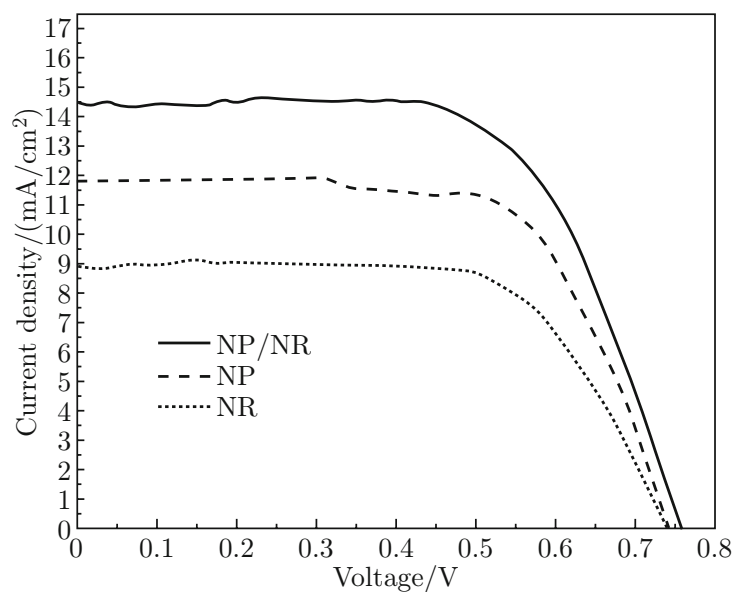

Fig. 13 Photocurrent density-voltage (J-V) curves of DSC constructed with $\mathrm{TiO}_{2}$ pure (nanoparticle), pure (nanorod) and bilayer (NR/NP) photoanode.

In recent years, new methods have been developed for synthesis of $\mathrm{TiO}_{2}$ nanorods and its applications in DSCs have been reported [77-79]. Shalan et al. synthesized Titania nanorods with controlled size for DSC via hydrothermal route at low hydrothermal temperature of $100^{\circ} \mathrm{C}$ for $24 \mathrm{~h}$ [80]. The size of the titania nanorods was $6.7 \mathrm{~nm}$ in width and $22 \mathrm{~nm}$ in length (Fig. 14). The results indicated that the bulk traps and the surface states within the $\mathrm{TiO}_{2}$ nanorods films have enhanced the efficiency of DSCs. The high sur- face area can provide more sites for dye adsorption, while the fast photoelectron-transfer channel can enhance the photogenerated electron transfer to complete the circuit. A nearly quantitative absorbed photon-toelectrical current conversion achieved upon excitation at wave length of $550 \mathrm{~nm}$ and the power efficiency was enhanced from $5.6 \%$ for commercial $\mathrm{TiO}_{2}$ nanoparticles Degussa (P25) cells to $7.20 \%$ for $\mathrm{TiO}_{2}$ nanorods cells under AM 1.5 illumination $\left(100 \mathrm{~mW} / \mathrm{cm}^{2}\right)$. The $\mathrm{TiO}_{2}$ cells performance was improved due to their high surface area, hierarchically mesoporous structures and fast electron transfer rate compared with the Degussa (P25) (Fig. 15) [80].

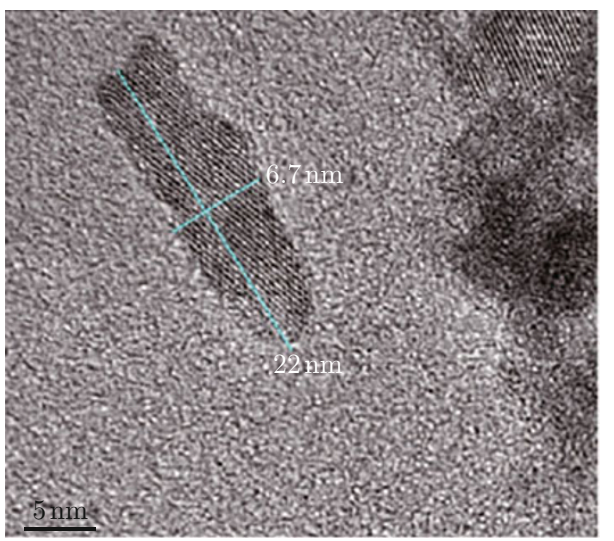

Fig. 14 HRTEM image of $\mathrm{TiO}_{2}$ nanorods synthesis by hydrothermal method. 


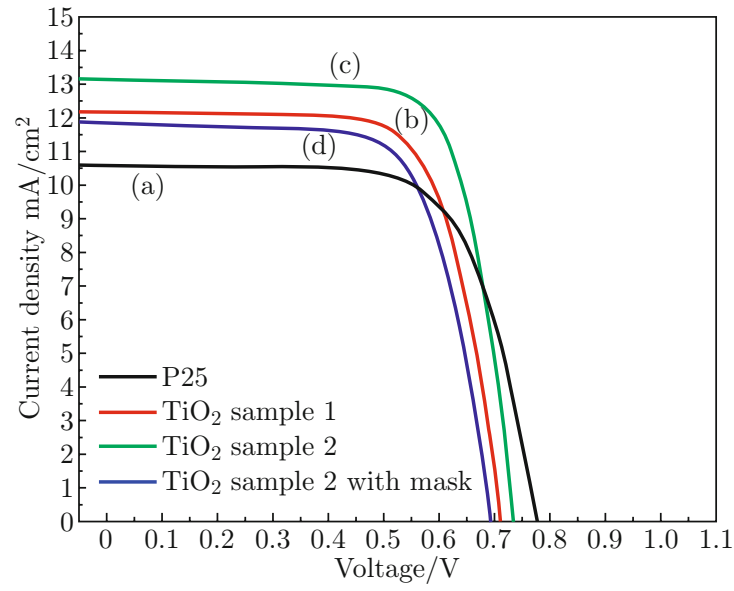

Fig. 15 Comparison of the I-V characteristics of DSSCs made of P25 commercial paste and $\mathrm{TiO}_{2}$ nanorods with different electrodes: (a) P25 commercial paste; (b) $\mathrm{TiO}_{2}$ nanorods sample 1, (c) $\mathrm{TiO}_{2}$ nanorods Sample 2; and (d) $\mathrm{TiO}_{2}$ nanorods Sample 2 with mask.
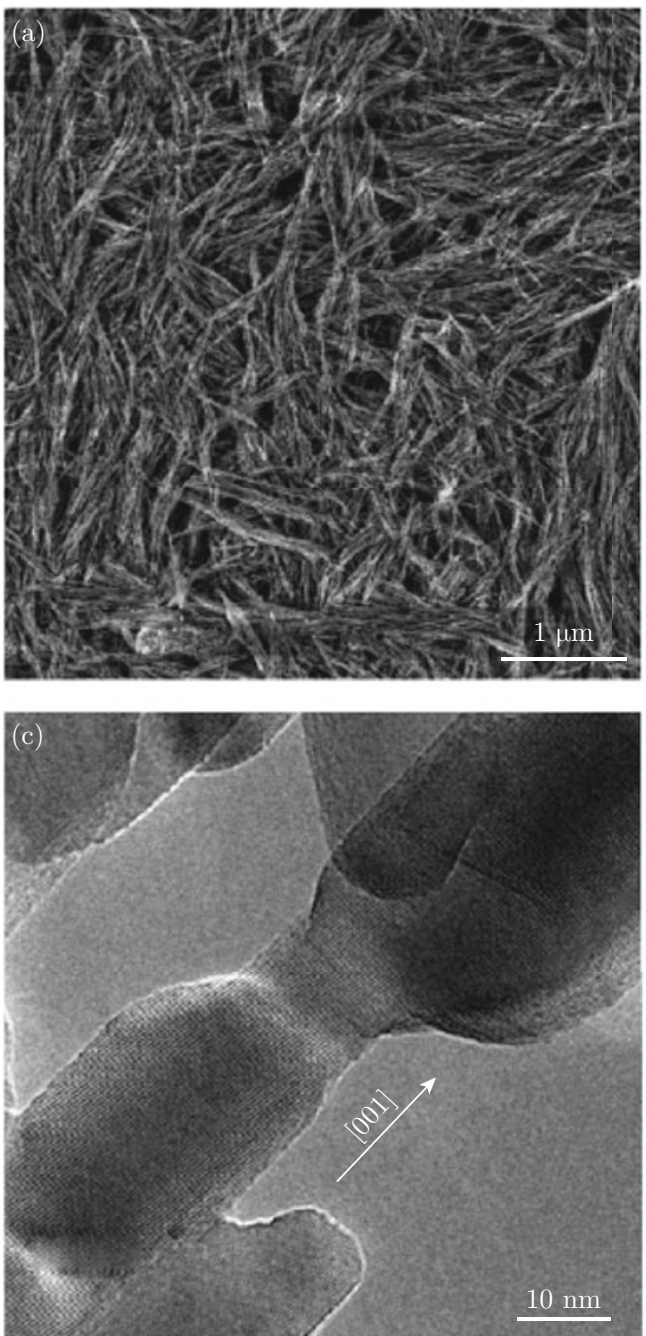

\section{Nano-pattered $\mathrm{TiO}_{2}$ structures}

At the recent years, reported many new developments for fabrication nano-patterned $\mathrm{TiO}_{2}$ structures and its application for DSCs [81,82]. For example, Tetreault et al. developed a novel morphology for solidstate dye-sensitized solar cells based on the simple and straightforward self-assembly of nanorods into a 3D (dimensional) fibrous network of fused single-crystalline anatase nanowires [69] (Fig. 16). This architecture offers a high roughness factor, significant light scattering, and up to several orders of magnitude faster electron transport to reach a near-record-breaking conversion efficiency of $4.9 \%$. Figure 17 shows the J-V for the bare 3D fibrous network DSCs as well as for cells which have been treated in aqueous acidic $\mathrm{TiCl}_{4}$ or by atomic layer deposition (ALD) of $\mathrm{TiO}_{2}(<1 \mathrm{~nm})$ to improve interconnectivity [69].
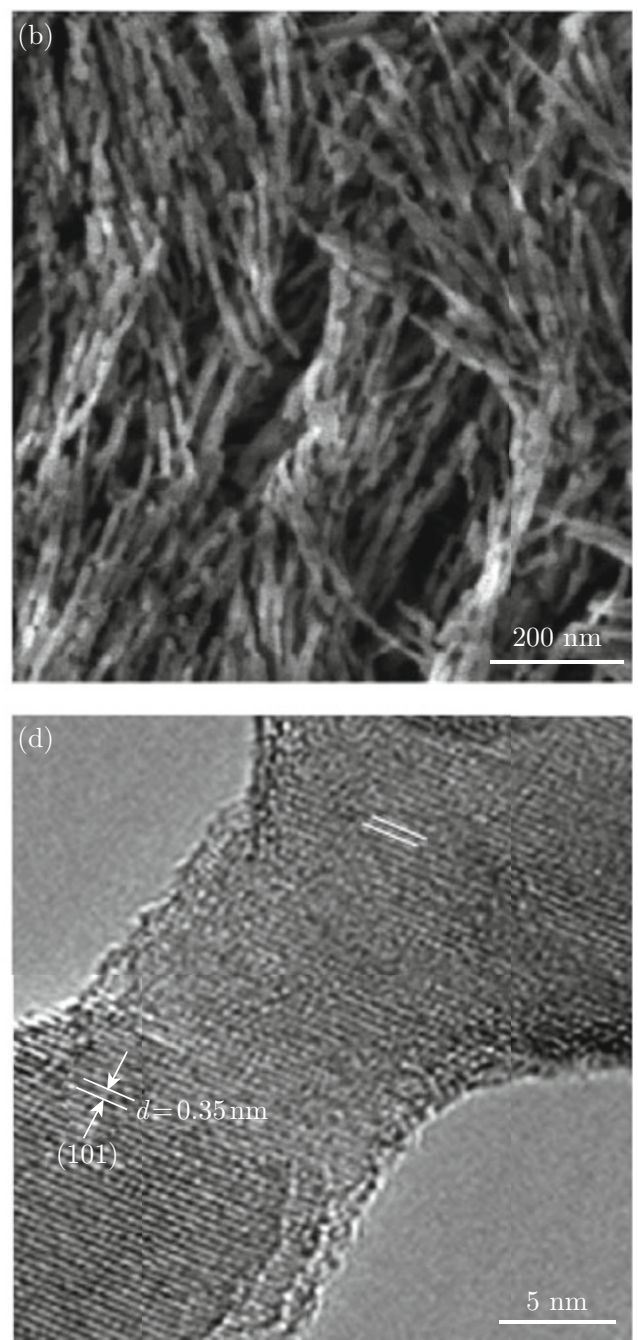

Fig. 16 Oriented attachment of nanorods into a 3D fibrous network of single-crystalline anatase nanowires: (a) Highresolution scanning electron micrograph of the top surface showing nanowire aggregates and the macroporous structure; (b) Oriented self-assembly of the nanorods into the 3D fibrous network; (c) High-resolution transmission electron micrograph showing the continuous [001] crystal orientation across two nanorods; (d) Continuous (101) crystal plane and spacing across the junction. 


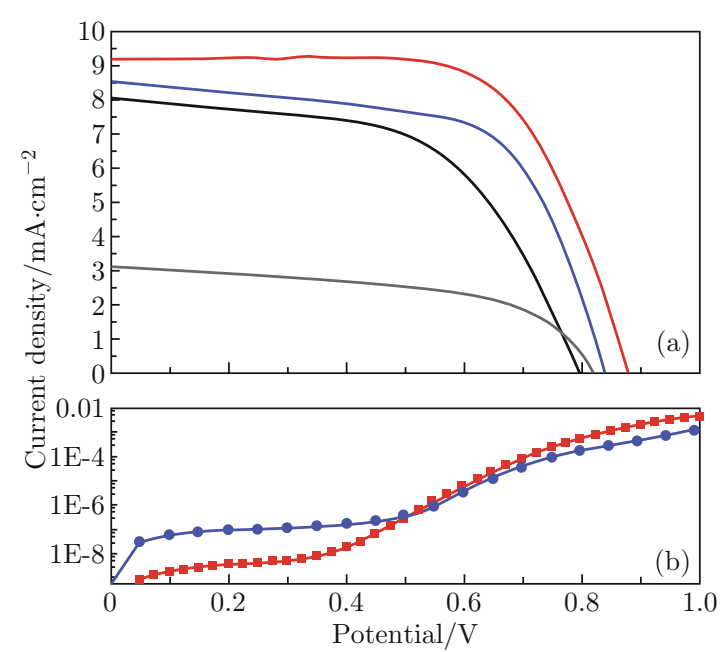

Fig. 17 (a) J-V characteristics for the as-prepared (gray, $\left.J_{\mathrm{sc}}=3.1 \mathrm{~mA} / \mathrm{cm}^{2}, \quad V \mathrm{oc}=820 \mathrm{mV}, \quad \mathrm{FF}=0.55, \quad n=1.5 \%\right)$, $\mathrm{TiCl}_{4}$ treated (black, $J s c=8.0 \mathrm{~mA} / \mathrm{cm}^{2}, \quad V$ oc $=795$ $\mathrm{mV}, \mathrm{FF}=0.56, n=3.9 \%$ ), ALD-treated electrodes (blue, $\left.J_{\mathrm{sc}}=8.50 \mathrm{~mA} / \mathrm{cm}^{2}, \quad V \mathrm{oc}=838 \mathrm{mV}, \mathrm{FF}=0.63, n=4.9 \%\right)$, and $\mathrm{TiCl}_{4}$-treated nanoparticle-based cell (red, $J_{\mathrm{sc}}=9.1$ $\mathrm{mA} / \mathrm{cm}^{2}, V$ oc $=881 \mathrm{mV}, \mathrm{FF}=0.67, n=5.4 \%$ ); (b) comparison of the dark current for a conventional nanoparticle film (red) and the 3D fibrous network film (blue).

\section{Conclusion}

Over the past decades, the tremendous effort put into $\mathrm{TiO}_{2}$ nanomaterials has resulted in a rich database for their synthesis, properties, modifications, and applications. Accompanied by the progress in the synthesis of $\mathrm{TiO}_{2}$ nanoparticles are new findings in the synthesis of $\mathrm{TiO}_{2}$ nanorods, nanotubes, nanowires, as well as mesoporous and photonic structures. The present article tries to give an overview of the current state of using titania nanostructures in dye sensitized solar cells.

The role of $\mathrm{TiO}_{2}$ appears to be critical in the improvement of the DSC performances. However, while the optimization of the $\mathrm{TiO}_{2}$ structure, crystallinity, surface chemistry, and of the deposition processes adopted for the cell fabrication may increase the cell performance (such as higher energy conversion efficiency), it may also drastically increase the overall cost of the cell and, therefore will not necessarily increase the chances for successful commercialization. Also, several issues relating to practical solar cell construction, such as, front or backside illumination, optimized layout, surface reflectivity, or designed light absorption are further open research areas and exciting new findings can also be expected in the development in these "technology" areas.

\section{Acknowledgment}

The authors are grateful for a grant from University of Tehran.

\section{References}

[1] M. I. Baraton, Nano- $\mathrm{TiO}_{2}$ for Dye-Sensitized Solar Cells Recent Patents on Nanotechnology 6, 10 (2012). http://dx.doi.org/10.2174/187221012798109273

[2] M. A. Green, K. Emery, Y. Hishikawa, W. Warta and E. D. Dunlop, Solar cell efficiency tables (version 39), Progress in Photovoltaics: Research and Applications 20, 12 (2012). http://dx.doi.org/10.1002/pip. 2163

[3] B. O'Regan, M. Gratzel, Nature 353, 737 (1991). http://dx.doi.org/10.1038/353737a0

[4] M. K. Nazeeruddin, S. M. Zakeeruddin, J. J. Lagref, P. Liska, P. Comte, C. Barolo, G. Viscardi, K. Schenk and M. Graetzel, Coordin. Chem. Rev. 248, 1317 (2004). http://dx.doi.org/10.1016/j.ccr.2004.03.012

[5] C. J. Barbé, F. Arendse, P. Comte, M. Jirousek, F. Lenzmann, V. Shklover and M. Grätzel, J. Am. Ceram. Soc. 80, 3157 (1997). http://dx.doi.org/10.1111/j. 1151-2916.1997.tb03245.x

[6] M. Grätzel, Accounts. Chem. Res. 42, 1788 (2009). http://dx.doi.org/10.1021/ar900141y

[7] P. Wang, S. M. Zakeeruddin, P. Comte, R. Charvet, R. Humphry-Baker and M. Grätzel, J. Phys. Chem. B 107, 14336 (2003). http://dx.doi.org/10.1021/ jp0365965

[8] K. D. Benkstein, N. Kopidakis, J. van de Lagemaat and A. J. Frank, J. Phys. Chem. B 107, 7759 (2003). http://dx.doi.org/10.1021/jp0226811

[9] W. Tan, X. Yin, X. Zhou, J. Zhang, X. Xiao and Y. Lin, Electrochim. Acta 54, 4467 (2009). http://dx. doi.org/10.1016/j.electacta.2009.03.037

[10] K. D. A. T. Geoprey Meacock, Michael J Knowles and Aristoteles Himonides, J. Sci. Food Agric. 73, 221 (1997).

[11] D. P. Macwan, P. Dave and S. Chaturvedi, J. Mater. Sci. 46, 3669 (2011). http://dx.doi.org/10.1007/ s10853-011-5378-y

[12] X. Tang, J. Qian, Z. Wang, H. Wang, Q. Feng and G. Liu, Colloid Interf. Sci. 330, 386 (2009). http://dx. doi.org/10.1016/j.jcis. 2008.10.072

[13] L. W. Fan Zuo, Tao Wu, Zhenyu Zhang, Dan Borchardt and Pingyun Feng, J. Am. Chem. Soc. 132, 11856 (2010).

[14] Y. Masuda and K. Kato, Thin Solid Films 516, 2547 (2008). http://dx.doi.org/10.1016/j. tsf.2007.04.063

[15] M. Gratzel, Nature 414, 338 (2001). http://dx.doi. org/10.1038/35104607

[16] A. Hagfeldt and M. Gratzel, Acc. Chem. Res. 33, 269 (2000). http://dx.doi.org/10.1021/ar980112j

[17] P. Wang, S. M. Zakeeruddin, J. E. Moser, M.K. Nazeeruddin, T. Sekiguchi and M. Gratzel, Nat. Mater. 2, 402 (2003). http://dx.doi.org/10.1038/ nmat 904 
[18] S. Pelet, J. E. Moser and M. Grätzel, J. Phys. Chem. B 104, 1791 (2000). http://dx.doi.org/10.1021/ jp9934477

[19] A. Hagfeldt and M. Grätzel, Acc. Chem. Res. 33, 269 (2000). http://dx.doi.org/10.1021/ar980112j

[20] V. S. Shelly D. Burnside, Christophe Barbé, Pascal Comte, Francine Arendse, Keith Brooks and Michael Grätzel, Chem. Mater. 10, 2419 (1998).

[21] M. Grätzel, J. Photochem. Photobiol. C. 4, 145 (2003). http://dx.doi.org/10.1016/ S1389-5567 (03) 00026-1

[22] A. Hagfeldt, G. Boschloo, L. Sun, L. Kloo and H. Pettersson, Chem. Rev. 110, 6595 (2010). http://dx.doi. org/10.1021/cr900356p

[23] X. Chen, S. S. Mao, Chem. Rev. 107, 2891 (2007). http://dx.doi.org/10.1021/cr0500535

[24] M. Gratzel, J. Colloid Interf. Sci. 4, 314 (1999). http://dx.doi.org/10.1016/ S1359-0294 (99) 90013-4

[25] O. K. Varghese and C. A. Grimes, J. Nanosci. Nanotechnol. 3, 277 (2003). http://dx.doi.org/10.1166/ jnn. 2003. 158

[26] Y. G. Guo, J. S. Hu, H. P. Liang, L. J. Wan and C. L. Bai, Adv. Funct. Mater. 15, 196 (2005). http://dx. doi.org/10.1002/adfm. 200305098

[27] Hoda Hafez, Zhang Lan, Qinghua Li, Jihuai Wu and H. Hafez, Nanotechnology, Science and Applications 3, 45 (2010). http://dx.doi.org/10.2147/NSA.S11350

[28] S. J. Limmer, S. Seraji, Y. Wu, T. P. Chou, C. Nguyen and G. Z. Cao, Adv. Funct. Mater. 12, 59 (2002). http://dx.doi.org/10.1002/ 1616-3028(20020101) 12: 1<59: : AID-ADFM59>3. $0 . \mathrm{CO} ; 2-\mathrm{B}$

[29] M. Zukalova, A. Zukal, L. Kavan, M. K. Nazeeruddin, P. Liska and M. Gratzel, Nano Lett. 5, 1789 (2005). http://dx.doi.org/10.1021/n10514011

[30] P. Roy, S. Berger and P. Schmuki, Angewandte Chemie 50, 2904 (2011). http://dx.doi.org/10.1002/anie. 201001374

[31] P. Roy, D. Kim, K. Lee, E. Spiecker and P. Schmuki, Nanoscale 2, 45 (2010). http://dx.doi.org/10.1039/ b9nr00131j

[32] J. Nelson, Phys. Rev. B 59, 15374 (1999). http://dx. doi.org/10.1103/PhysRevB.59.15374

[33] J. Bisquert, Phys. Rev. Lett. 91, 010602 (2003). http://dx.doi.org/10.1103/PhysRevLett. 91. 010602

[34] A. G. James R. Jennings, Laurence M. Peter, Patrik Schmuki and Alison B. Walker, J. Am. Chem. Soc. 130, 13364 (2008).

[35] Y. S. S. Nakade, W. Kubo, T. Kitamura, Y. Wada and S. Yanagida, J. Phys. Chem. B 107, 8607 (2003). http://dx.doi.org/10.1021/jp034773w

[36] J. Bai, B. Zhou, L. Li, Y. Liu, Q. Zheng, J. Shao, X. Zhu, W. Cai, J. Liao and L. Zou, J. Mater. Sci. 43, 1880 (2008). http://dx.doi.org/10.1007/ s10853-007-2418-8
[37] Y. Liu, B. Zhou, B. Xiong, J. Bai and L. Li, Chin. Sci. Bull. 52, 1585 (2007). http://dx.doi.org/10.1007/ s11434-007-0254-5

[38] A. Ghicov, S. P. Albu, R. Hahn, D. Kim, T. Stergiopoulos, J. Kunze, C. A. Schiller, P. Falaras and P. Schmuki, Chem. Asian J. 4, 520 (2009). http://dx. doi.org/10.1002/asia. 200800441

[39] D. Kim, A. Ghicov and P. Schmuki, Electrochem. Commun. 10, 1835 (2008). http://dx.doi.org/10. 1016/j.elecom. 2008.09.029

[40] S. H. Kang, S. H. Choi, M. S. Kang, J. Y. Kim, H. S. Kim, T. Hyeon and Y. E. Sung, Adv. Mater. 20, 54 (2008). http://dx.doi.org/10.1002/adma. 200701819

[41] S. Pavasupree, S. Ngamsinlapasathian, Y. Suzuki and S. Yoshikawa, J. Nanosci. Nanotechnol. 6, 3685 (2006). http://dx.doi.org/10.1166/jnn.2006.612

[42] K. Zhu, T. B. Vinzant, N. R. Neale and A. J. Frank, Nano Lett. 7, 3739 (2007). http://dx.doi.org/10. $1021 / \mathrm{n} 1072145 \mathrm{a}$

[43] J. R. Jennings, A. Ghicov, L. M. Peter, P. Schmuki and A. B. Walker, J. Am. Chem. Soc. 130, 13364 (2008). http://dx.doi.org/10.1021/ja804852z

[44] P. Charoensirithavorn, Y. Ogomi, T. Sagawa, S. Hayase and S. Yoshikawa, J. Electrochem. Soc. 157, B354 (2010). http://dx.doi.org/10.1149/1. 3280229

[45] H. H. Ou and S. L. Lo, Sep. Purif. Technol. 58, 179 (2007). http://dx.doi.org/10.1016/j.seppur. 2007.07.017

[46] G. R. Patzke, F. Krumeich and R. Nesper, Angew. Chem. Int. Ed. 41, 2446 (2002). http://dx.doi. org/10.1002/1521-3773(20020715) 41: 14<2446: : AID-ANIE2446>3 . 0.CO;2-K

[47] D. V. Bavykin, J. M. Friedrich and F. C. Walsh, Adv. Mater. 18, 2807 (2006). http://dx.doi.org/10.1002/ adma. 200502696

[48] J. M. Macak, H. Tsuchiya, A. Ghicov, K. Yasuda, R. Hahn, S. Bauer and P. Schmuki, Curr. Opin. Solid State Mater. Sci. 11, 3 (2007). http://dx.doi.org/ $10.1016 / j$. cossms . 2007.08.004

[49] V. Zwilling, E. Darque-Ceretti, A. Boutry-Forveille, D. David, M. Y. Perrin and M. Aucouturier, Surf. Interface Anal. 27, 629 (1999). http://dx.doi. org/10. 1002/(SICI) 1096-9918(199907) $27: 7<629:$ : AID-SIA551>3.0.CO;2-0

[50] R. Beranek, H. Hildebrand and P. Schmuki, Electrochem. Solid-State Lett. 6, B12 (2003). http://dx. doi.org/10.1149/1.1545192

[51] J. M. Macak, K. Sirotna and P. Schmuki, Electrochim. Acta. 50, 3679 (2005). http://dx.doi.org/10.1016/ j.electacta.2005.01.014

[52] J. M. Macak, H. Tsuchiya, L. Taveira, S. Aldabergerova and P. Schmuki, Angew. Chem. Int. Ed. 44, 7463 (2005). http://dx.doi.org/10.1002/anie. 200502781

[53] J. M. Macák, H. Tsuchiya and P. Schmuki, Angew. Chem. Int. Ed. 44, 2100 (2005). http://dx.doi.org/ 10.1002/anie. 200462459 
[54] M. Adachi, Y. Murata, I. Okada and S. Yoshikawa, J. Electrochem. Soc. 150, G488 (2003). http://dx.doi. org/10.1149/1.1589763

[55] J. M. Macak, F. Schmidt-Stein and P. Schmuki, Electrochem. Commun. 9, 1783 (2007). http://dx.doi. org/10.1016/j.elecom. 2007.04.002

[56] Y. Ohsaki, N. Masaki, T. Kitamura, Y. Wada, T. Okamoto, T. Sekino, K. Niihara and S. Yanagida, Phys. Chem. Chem. Phys. 7, 4157 (2005). http://dx. doi.org/10.1039/b511016e

[57] G. K. Mor, K. Shankar, M. Paulose, O. K. Varghese and C. A. Grimes, Nano Lett. 6, 215 (2006). http:// dx.doi.org/10.1021/nl052099j

[58] M. Paulose, K. Shankar, O. K. Varghese, G. K. Mor, B. Hardin and C. A. Grimes, Nanotech. 17, 1446 (2006). http://dx.doi.org/10.1088/0957-4484/17/5/046

[59] L. L. Li, C. Y. Tsai, H. P. Wu, C. C. Chen and E. W. G. Diau, J. Mater. Chem. 20, 2753 (2010). http://dx. doi.org/10.1039/b922003h

[60] J. D. Berrigan, T. S. Kang, Y. Cai, J. R. Deneault, M. F. Durstock and K. H. Sandhage, Adv. Funct. Mater. 21, 1693 (2011). http://dx.doi.org/10.1002/adfm. 201002676

[61] J. J. Hill, N. Banks, K. Haller, M. E. Orazem and K. J. Ziegler, J. Am. Chem. Soc. 133, 18663 (2011). http:// dx.doi.org/10.1021/ja2044216

[62] L. Sun, S. Zhang, X. Wang, X. W. Sun, D. Y. Ong and A. K. Ko Kyaw, Energy Environ. Sci. 4, 2240 (2011).

[63] K. L. Li, Z. B. Xie and S. Adams, Electrochim. Acta 62, 116 (2012). http://dx.doi.org/10.1016/j. electacta.2011.11.118

[64] Qing Zheng, Hosung Kang, Jongju Yun, Jiyong Lee, Jong Hyeok Park and Seunghyun Baik, ACS Nano 5, 5088 (2011). http://dx.doi.org/10.1021/nn201169u

[65] Q. Zhang and G. Cao, Nano Today 6, 91 (2011). http://dx.doi.org/10.1016/j.nantod.2010.12.007

[66] Xinjian Feng, Karthik Shankar, Oomman K. Varghese, Maggie Paulose, Thomas J. Latempa and Craig A. Grimes, Nano Lett. 8, 3781 (2008).

[67] Bin Liu and Eray S. Aydil, J. Am. Chem. Soc. 131, 3985 (2009). http://dx.doi.org/10.1021/ja8078972

[68] L. Sun, S. Zhang, X. Wang, X. W. Sun, D. Y. Ong, X. Wang and D. Zhao, Chem. Phys. Chem. 12, 3634 (2011). http://dx.doi.org/10.1002/cphc. 201100450
[69] E. H. N. Tetreault, T. Moehl, J. Brillet, R. Smajda, S. Bungener, N. Cai, P. Wang, S. M. Zakeeruddin, L. Forro, A. Magrez and M. Graetzel, ACS Nano 4, 7644 (2010). http://dx.doi.org/10.1021/nn1024434

[70] M. Law, L. E. Greene, J. C. Johnson, R. Saykally and P. Yang, Nat. Mater. 4, 455 (2005). http://dx.doi. org/10.1038/nmat1387

[71] X. L. Jijun Qiu, Fuwei Zhuge, Xiaoyan Gan, Xiangdong Gao, Weizhen He Se-Jeong Park, HyungKook Kim and Yoon-Hwae Hwang, Nanotechnology 21, 195602 (2010).

[72] H. Horiuchi, R. Katoh, K. Hara, M. Yanagida, S. Murata, H. Arakawa and M. Tachiya, J. Phys. Chem. B 107, 2570 (2003). http://dx.doi.org/10.1021/ jp0220027

[73] Z. Wei, R. Li, T. Huang and A. Yu, Electrochim. Acta, 56, 7696 (2011). http://dx.doi.org/10.1016/ j.electacta.2011.06.038

[74] X. Feng, J. Zhai and L. Jiang, Angew. Chem. Inter. Ed. 44, 5115 (2005).

[75] Qinghong Zhang and Lian Gao, Langmuir 19, 967 (2003). http://dx.doi.org/10.1021/la020310q

[76] Q. Huang and L. Gao, Chem. Lett. 32, 638 (2003). http://dx.doi.org/10.1246/cl.2003.638

[77] R. S. Chen, C. A. Chen, et al., Appl. Phys. Lett. 100, 123108 (2012). http://dx.doi.org/10.1063/1. 3694926

[78] T. Y. Tsai and S. Y. Lu, J. Electrochem. Soc. 158, B1306 (2011). http://dx.doi.org/10.1149/2. 023111jes

[79] G. Melcarne, L. De Marco, E. Carlino, F. Martina, M. Manca, R. Cingolani, G. Gigli and G. Ciccarella, J. Mater. Chem. 20, 7248 (2010). http://dx.doi.org/ 10.1039/c0jm01167c

[80] A. E. Shalan, M. M. Rashad, Y. Yu, M. Lira-Cantú, M. S. A. Abdel-Mottaleb, Appl. Phys. A (2012). http:// dx.doi .org/10.1007/s00339-012-7368-6

[81] J. Kim, J. K. Koh, B. Kim, J. H. Kim and E. Kim, Angew. Chem. Inter. Ed. 51, 6864 (2012).

[82] S. H. T. Stefan Guldin, Matthias Kolle, Mark E. Welland, Peter Müller-Buschbaum, Richard H. Friend, Ullrich Steiner and Nicolas Tétreault, Nano Lett. 10, 2303 (2010). 